\title{
PRINSIP - PRINSIP GOOD GOVERNANCE DI DINAS KEPENDUDUKAN DAN CATATAN SIPIL KOTA PEKANBARU
}

\author{
Surya Dailiati, Hernimawati Dan Sudaryanto \\ Universitas lancang Kuning \\ Email : surya-dailiati@unilak.ac.id
}

\begin{abstract}
Abstrak
Instansi publik yang memberikan pelayanan publik yang akuntabel, transparan, mudah dijangkau, informasi mudah diakses merupakan beberapa ciri instasi publik yang telah menerapkan prinsip good governance. Dinas Kependudukan dan Pencatatan Sipil Kota Pekanbaru merupakan instansi publik yang menyelenggarakan pelayanan publik dibidang kependudukan dan pencatatan sipil, diantaranya adalah pelayanan Kartu Tanda Penduduk, Kartu Keluarga, pencatatan dan penerbitan akta kelahiran serta kematian.

Penelitian ini bertujuan untuk mengetahui bagaimana prinsip -prinsip good governance.Penelitian ini merupakan penelitian deskriptif kualitatif.Teknik sampling yang digunakan adalah teknik purposive sampling.Teknik pengumpulan data menggunakan observasi dan wawancara serta kuesioner.Sumber data yang digunakan dalam penelitian ini adalah aparatur sipil negara dan masyarakat yang mengurus administrasi.Data yang diperoleh, dianalisis menggunakan teknik analisis deskriftif yang terdiri dari reduksi data, sajian data dan penarikan kesimpulan. Berdasarkan penelitian bahwa penerapan prinsip-prinsip good governance sudah baik tetapi ada beberapa yang perlu ditingkatkan.Yakni, kesetaraan dan tegaknya supremasi hukum.Untuk itu perlu adanya peningkatan pada beberapa aspek.
\end{abstract}

Kata kunci : Prinsip, Good Governance, Instansi Publik

Abstract

Public agencies that provide public services accountable, transparent, accessible, easily accessible information is a public instasi some traits that have applied the principles of good governance. Office of Population and Civil Registration Pekanbaru is the public agency that organizes public services in the field of population and civil registration, including the service of National Identity Card, Family Card, registration and issuance of birth certificates and death.

This study aims to determine how the Principles of good governance. This research is a qualitative descriptive study. The sampling technique used was purposive sampling technique. Data collection technique used observation and interview and questionnaire. The data used in this study is the apparatus of the state and civil society is managing the administration. The data obtained were analyzed using descriptive analysis technique that consists of data reduction, data presentation and conclusion. Based on the research that the application of the principles of good governance is good but there are some that need to be improved. Namely, equality and the supremacy of law. For that we need an improvement in some aspects.

Keywords: Principles, Good Governance, Public Agencies

\section{PENDAHULUAN}

Penyelenggaraan pemerintahan di kenal istilah Good Government dan Good Governance.Good government adalah suatu kesepakatan menyangkut pengaturan negara yang diciptakan bersama oleh pemerintah, masyarakat madani, dan swasta. Sedangkan Good Governance adalah adalah suatu peyelegaraan manajemen pembangunan yang solid dan bertanggung jawab yang sejalan dengan prinsip demokrasi dan pasar yang efisien, penghindaran salah alokasi dana investasi dan pencegahan 
korupsi baik secara politik maupun secara administratif menjalankan disiplin anggaran serta penciptaan legal dan politican framework bagi tumbuhnya aktifitas usaha. Secara sederhana govermennt Berkaitan dengan aturan sedangkan governance pelaksanaan aturan. Secara umum pemerintah telah menerapkan good government, kini tinggal lagi aparatur sipil negara untuk melaksanakannya. Seperti yang terjadi di Dinas Kependudukan Dan Catatan Sipil Kota Pekanbaru.Dengan visi"Terwujudnya Pelayanan Administrasi Kependudukan Yang Tertib,Cepat Dan Akurat", dinas ini telah melakukan berbagai upaya, hanya saja masih terdapat keluhan dari masyarakat dalam penyelenggaraan pemeritahan. Seperti kejelasan biaya administrasi yang belum standar dan sanksi hukum yang belum berjalan sesuai dengan ketentuan yang berlaku. Artinya,prinsip-prinsip tata laksana pemerintahan yang baik (good governance) khususnya tegaknya supremasi hukum dan transparansi Belum berjalan dengan baik. Penyimpangan yang terjadi belum dilakukan penindakan dan retribusi yang dibuat belum teradministrasi sesuai dengan ketentuan yang berlaku. Padahal Good governance menunjuk pada pengertian bahwa kekuasaan tidak lagi semata-mata dimiliki atau menjadi urusan pemerintah, tetapi menekankan pada pelaksanaan fungsi pemerintahan secara bersama-sama oleh pemerintah, masyarakat madani, dan pihak swasta.

Pemerintah Kota Pekanbaru terdapat 32 Satuan Kerja Perangkat Daerah (SKPD) setingkat dinas/ badan.Dipilihnya Dinas Kependudukan Dan Catatan Sipil untuk kegiatan penelitian karena hanya dinas ini yang mengurus administrasi kependudukan masyarakat.

Tugas pokok Dinas Kependudukan Dan Catatan Sipil (Disdukcapil) adalah melaksanakan penyusunan dan kebijakan daerah di bidang kependudukan, catatan sipil dan transmigrasi. Fungsi dinas ini diantaranya; perumusan pelaksanaan kebijakan teknis kependudukan pencatatan sipil.

Kunci utama memahami good governance dalam pandangan masyarakat Transparansi Indonesia (MTI) adalah pemahaman atas prinsip - prinsip yang mendasarinya. Bertolak dari prinsip-prinsip ini didapat tolok ukur kinerja suatu pemerintah. Prinsip - prinsip tersebut kata Hardjasoemantri dalam Deddy Mulyadi (2015) meliputi:

1.Partisipasi Masyarakat,Semua warga masyarakat mempunyai suara dalam pengambilan keputusan, baik secara langsung maupun melalui lembaga perwakilansah yang mewakili kepentingan mereka.Partisipasi menyeluruh dibangun berdasarkan kebebasan berkumpul dan mengungkapkan pendapat, serta kapasitas untuk berpartisipasi secara konstruktif.

2.Tegaknya Supremasi Hukum, Kerangka hukum harus adil dan diberlakukan tanpa pandang bulu, termasuk di dalamnya hukum-hukum yang menyangkut hak asasi manusia.

3.Transparansi, Tranparansi dibangun atas dasar arus informasi yang bebas. Seluruh proses pemerintahan, lembaga-lembaga dan informasi perlu dapat diakses oleh pihak-pihak yang berkepentingan, dan informasi yang tersedia harus memadai agar dapat dimengerti dan dipantau.

4.Peduli pada Stakeholder, Lembaga- lembaga dan seluruh proses pemerintahan harus berusaha melayani semua pihak yang berkepentingan.

5.Berorientasi pada Konsensus, Tata pemerintahan yang baik menjembatani kepentingan-kepentingan yang berbeda demi terbangunnya suatu konsensus menyeluruh dan yang terbaik bagi kelompok masyarakat, dan terutama dalam kebijakan dan prosedur.

6.Kesetaraan, Semua warga masyarakat mempunyai kesempatan memperbaiki atau mempertahankan kesejahteraan.

7.Efektifitas dan Efisiensi, Proses -proses pemerintahan dan lembaga -lembaga membuahkan hasil sesuai kebutuhan warga masyarakat dan dengan menggunakan sumber-sumber daya yang ada seoptimal mungkin.

8.Akuntabilitas, Para pengambil keputusan di pemerintah, sektor swasta dan organisasi-organisasi masyarakat bertanggung jawab baik kepada masyarakat maupun kepada lembaga-lembaga yang berkepentingan.Bentuk pertanggung jawaban tersebut tergantung dari jenis organisasi yang bersangkutan. 
9. Visi Strategis, Para pemimpin dan masyarakat memiliki perspektif yang luas dan jauh ke depan atas tata pemerintahan yang baik dan pembangunan manusia, serta kepekaan untuk mewujudkannya, harus memiliki pemahaman atas kompleksitas kesejarahan, budaya dan sosial yang menjadi dasar bagi perspektif tersebut. Dalam Jurnal Niara Volume 8 Nomor 2, dikatakan agar masyarakat bisa menjalankan peraturan daerah perlu diberikan sanksi. Artinya, ada ancaman berupa sanksi bagi mereka yang tidak mematuhi kebijakan publik. Hal ini secara langsung akan mendukung terlaksananya prinsip-prinsip good governance di lembaga pemerintah.

\section{METODE}

Penelitian dilakukan di Kantor Dinas Kependudukan dan Catatan Sipil Kota Pekanbaru. Populasi dan sampel dalam mereka. Penelitian ini adalah Aparatur Sipil Negara yang bertugas di Kantor Dinas Kependudukan Dana Catatan Sipil Kota Pekanbaru.Teknik penarikan sampel yang digunakan adalah sensus untuk aparatur pemerintah dan teknik aksidental untuk masyarakat. Untuk menghimpun data yang diperlukan, maka di pergunakan teknik pengumpulan data dengan cara observasi, wawancara dan kuesioner.Data yang telah terkumpul berdasarkan jenis dan bentuk data, untuk selanjutnya data dianalisis secara deskriptif kualitatif.

\section{HASIL DAN PEMBAHASAN}

Dari penelitian yang telah dilakukan diketahui bahwa Dinas Kependudukan Dan Catatan Sipil Kota Pekanbaru telah menerapkan Prinsip- prinsip good governance yang meliputi ; partisipasi masyarakat, tegaknya supremasi hukum,transparansi, kepedulian pada stakeholder. Kemudian berorientasi pada konsensus, kesetaraan, efektifitas dan Efisiensi serta akuntabilitas dan visi strategis. Hal ini dibuktikan dengan akuratnya data kependudukan yang dapat memberikan gambaran, acuan dan pedoman Pemerintah dalam memgambil suatu kebijakan dan mengetahui Sistem Informasi Adminstrasi Kependudukan (SIAK)yang ada pada Pemerintah Kota Pekanbaru, termasuk dalam melihat kesenjangan yang ada. Dari gambaran tersebut dapat memberikan sejumlah rekomendasi untuk menyusun kebijakan daerah, penelitian dan sebagai dasar bagi pendataan yang lain misalnya menggambarkan proporsi dan jumlah pengangguran dan sebagainya. Data Kependudukan Kota Pekanbaru dapat digunakan oleh instansi pemerintah /swasta maupun pihak-pihak lain yang membutuhkan. Data kependudukan berdasarkan registrasi kependudukan pada Dinas Kependudukan dan Pencatatan Sipil Kota Pekanbaru. Kedepan akan dilakukan berbagai usaha untuk menyajikan data yang lebih akurat dan valid, antara lain dengan memperbaiki sistem yang ada di Dinas Kependudukan dan Pencatatan Sipil Kota Pekanbaru. Data yang valid dan akurat juga sangat tergantung pada karakter dan perilaku masyarakat sendiri sehingga di harapkan masyarakat yang melakukan registrasi dan pengurusan di Dinas Kependudukan dan Pencatatan Sipil Kota Pekanbaru mengisi biodatanya dengan benar dan lengkap serta tidak terlambat melakukan registrasi.

Kepemilikan Kartu Keluarga Kartu Keluarga merupakan salah satu dari beberapa dokumen kependudukan yang wajib dimiliki oleh keluarga.Kartu keluarga menunjukkan hubungan kekerabatan antara kepala keluarga dengan anggota keluarganya.Untuk menghindari kepala keluarga ganda, maka perempuan bisa menjadi kepala keluarga karena status perkawinannya janda maupun karena menjadi istri kedua, ketiga maupun keempat dari seorang laki-laki, sedangkan suaminya menjadi kepala keluarga hanya di salah satu istri, sesuai kesepakatan di dalam keluarga tersebut. Seorang kepala keluarga bertanggung jawab terhadap anggota keluarga. Kartu Keluarga (KK) merupakan kartu 
identitas yang memuat data tentang nama,susunan dan hubungan dalam keluarga, serta identitas anggota keluarga seperti umur, jenis kelamin, status perkawinan,status kegiatan,status pekerjaan, status kecacatan dan lain sebagainya. Tabel. 34.menunjukkan jumlah keluarga dan jumlah keluarga yang memiliki Kartu Keluarga SIAK di Kota Pekanbaru. dari 264.370 keluarga ternyata 246.426 keluarga yang memiliki Kartu Keluarga SIAK. Sedangkan 17.944 yang tidak memiliki KK SIAK sehingga perlu dicari faktor penyebabnya. Jadi persentase keluarga yang memiliki KK SIAK adalah 93,21\% Apabila menurut kecamatan, maka persentase kepemilikan KK SIAK yang paling rendah di Kecamatan Pekanbaru Kota (91.31 \%) sedangkan paling tinggi di Kecamatan Rumbai (95.29 \%). Kepemilikan Kartu Tanda Penduduk (KTP) Kartu Tanda Penduduk (KTP) merupakan salah satu identitas legal bagi penduduk yang menjadi bukti bahwa orang tersebut diakui sebagai penduduk di suatu wilayah administrasi di Indonesia. Berdasarkan UU Nomor 24 Tahun 2013, KTP wajib dimiliki oleh semua penduduk di Indonesia yang sudah berumur 17 tahun ke atas atau mereka yang berumur di bawah 17 tahun tetapi sudah pernah kawin, dalam profil ini disebut penduduk wajib KTP. Dengan memiliki KTP penduduk dapat dengan mudah mengurus semua yang berkaitan dengan legalitas serta memperoleh pelayanan sosial dan ekonomi dasar lainnya; misalnya urusan perbankan,mengurus sertifikat tanah, mengurus perkawinan, pendidikan, pekerjaan dan sebagainya.Tabel.4. menyajikan jumlah dan proporsi penduduk menurut kepemilikan KTP SIAK. Kepemilikan Akta merupakan dokumen kependudukan yang sangat penting dan wajib dimiliki oleh semua penduduk di Indonesia. Akta merupakan pengakuan Negara atas status keperdataan seseorang baik dalam hubungan kekeluargaan maupun dalam hubungannya dengan pelayanan legal lainnya. Akta-akta yang dimaksud meliputi akta kelahiran, akta kematian, akta perkawinan dan akta perceraian.

\section{KESIMPULAN}

1.Dinas Kependudukan Dan Catatan Sipil Kota Pekanbaru telah melaksanakan prinsip-prinsip good governance dengan baik.

2.Pelaksanaan prinsip-prinsip good governance belum berjalan secara maksimal.

\section{SARAN}

Oleh karena itu perlu dilakukan:

1.Memaksimalkan pelaksanaan prinsip- prinsip good governance di Kantor Dinas Kependudukan Dan Catatan Sipil Kota Pekanbaru.

2.Melakukan sosialisasi yang berhubungan dengan prinsip-prinsip good governane di setiap kecamatan dan kelurahan di Kota Pekanbaru.

\section{DAFTAR PUSTAKA}

[1]. Abu Ahmadi dan Noor Salimi, 2008, Dasar- Dasar Pendidikan Agama Islam, Bumi Aksara, Jakarta.

[2]. Agus Dkk, 2012, Modul Monitoring Penegakan Hukum, ICW, Jakarta.

[3]. Anggara Sahya. 2012. Perbandingan Administrasi Negara. CV Pustaka Setia, Bandung.

[4]. Beddy Iriawan, 2012.Sistem Politik Indonesia, Rajawali Pers, Jakarta

P-ISSN 1693-3516 | E-ISSN 2528-7575 
[5]. Danang Sunyoto dan Burhanuddin, 2011, Perilaku Organisasional, CAPS, Yogyakarta.

[6]. Deddy Mulyadi, 2015. Studi Kebijakan Publik Dan Pelayanan Publik, Alfabeta, Bandung.

[7]. Kaelan, 2010, Pendidikan Pancasila, Paradigma, Yogyakarta.

[8]. MPR RI, 2012, Ketetapan MPR RI Nomor I/ MPR/ $2003 \quad$ Tentang Peninjauan Kembali Materi dan Status Hukum Ketetapan MPR Sementara dan

[9].Ketetapan MPR RI Tahun 1960 -2002, Sekretariat Jenderal MPR RI, Jakarta

[10].Padmo Wahjono dan Nazaruddin, Syamsuddin, 2009, Pengantar Ilmu Politik, PT Raja Grafindo Persada, Jakarta

[11].Prihati, Prihati, Harsini, Harsini, \& Nasution, Sri. (2016). Profesionalisme Aparatur Sipil Negara (Asn) Di Kantor Camat Bukit Raya Kota Pekanbaru. Jurnal Niara, 9(1), 18-22. Https://Doi.Org/10.31849/Nia.V9i1.2014

[12].Riant Nugroho dan Randy Wrihatnolo, 2011, Manajemen Perencanaan Pembangunan,

[13].Ridwan HR, 2010, Hukum Administrasi Negara, PT Raja Grafindo Persada, Jakarta.

[14]. Saputra, Trio, Marlinda, Pebriana, \& Sufi, Wasiah. (2018). Pengaruh Gaya Kepemimpinan Transformasional Terhadap Efektifitas Kinerja Pegawai Puskesmas Rawat Inap Sidomulyo Barat Kota Pekanbaru. Jurnal Niara, 9(1), 10-17. Https://Doi.Org/10.31849/Nia.V9i1.2012

[15].Siti Fajar dan Tri Heru, 2013, Manajemen Sumber Daya Manusia, UPP STIM YKPN, Yogyakarta.

[16].Subhan Sofhian dan Asep Sahid, 2011,Pendidikan Kewarganegaraan, Fokus Media, Bandung.

[17].Wibowo, 2010, Budaya Organisasi, Rajawali Pres, Jakarta.

[18].Yusuf Muri, 2014, Metode Penelitian; Kuantitatif Kualitatif dan Penelitian Gabungan, Prenada Media Grup, Jakarta. 